\title{
ВЕЛИКОПРОЛІТНІ ПРОСТОРОВІ КОНСТРУКТИВНІ СИСТЕМИ, ЗАПРОЕКТОВАНІ ЗА БІОНІЧНИМИ ПРИНЦИПАМИ
}

\section{LARGE-SPAN SPATIAL STRUCTURAL SYSTEMS DESIGNED ACCORDING TO BIONIC PRINCIPLES}

Коломійчук Г.П., к.т.н., доцент, Майстренко О.Ф., к.т.Н., доцент, Коломійчук В.Г., аспірант, Коломійчук В.Г., студентка (Одеська державна академія будівництва та архітектури, м. Одеса)

Kolomiychuk G.P., PhD., associate professor, Maistrenko O.F., PhD., associate professor, Kolomiichuk V.G., postgraduate student, Kolomiichuk V.G., student (Odessa State Academy Civil Engineering and Architecture, Odessa)

Великопролітні просторові конструктивні системи найчастіше застосовуються в будівлях та спорудах, де одночасно перебуває велика кількість людей, тому їх проектування, зведення та експлуатація вимагає постійного вдосконалення. Одним із шляхів вирішення цієї проблеми $є$ пошук надійних природних аналогів і їх використання в просторових конструктивних системах.

Large-span spatial structural systems are most often used in buildings and structures where a large number of people are at the same time, therefore, their design, construction and operation require constant improvement. One of the ways to solve this problem is the search for reliable natural analogs and their use in spatial structural systems. The search for reliable natural analogues and their use in spatial structural systems is one of the most urgent tasks nowdays. Currently, the development of new options for spatial coatings, which were not previously used, and there is no experience in their operation, is being developed at a high pace. Approbation by experimental studies on models is ignored, and only a numerical experiment is used. But the behavior of large-span spatial structures under load is non-linear and difficult to predict, so the use of natural analogs is a guarantee of reliable operation.

The article analyzes new research on the use of bionic principles in large-span buildings and structures.Based on the study of the structure of constructive analogues of living nature, the principle of resilience in constructive systems has been established. Due to the use of resilience in the structure, its bearing capacity is restored without increasing the mass. Based on the principle of resilience, transformed coating designs have been developed.

According to the principle of heterogeneous material placement in structural systems, the combination of the geometry of polygonal cells with layering and their strong walls provide compactness, high strength and rigidity to structures with minimal material consumption. The use of layers with different properties makes it possible to obtain a sandwich type structure with high strength, rigidity and relatively low weight.

The principle of tight packing allows you to get the maximum usable volume with a 
minimum fence surface. In nature, it manifests itself in the optimization of biological forms in the case when the cells in the structure have constant geometric characteristics. So, bees building honeycombs form a dense pack of circles, which, under the action of capillary forces exceeding the pressure from the inside of the bee bodies, turn into the described hexagons. Splitting a plane into equal hexagonal elements has a minimum length.

The principle of the directional form of buckling makes it possible to avoid bifurcation of stable forms of equilibrium states in the design of structural systems, as well as to exclude the uncertainty of their further behavior under loads. Nature, creating constructive systems, deliberately tries to avoid possible transitions of initial deformations into other types, that is, excludes the loss of stability of the first kind.

According to the principle of the trajectory structure of structural systems, elements in the structures of living nature are placed in accordance with the geometry of the displacement field along the trajectories of principal stresses. The nature of the force field is determined by the type of external action and kinematic boundary conditions. Trajectory structures provide the required strength in relation to the given forces with an extremely limited amount of material. The orientation of the elements along the lines of force increases the strength and stiffness properties with a minimum amount of material used to create them.

Thus, large-span spatial structural systems designed using modern bionic principles are presented.

Ключові слова: великопролітні конструкиії, інженерно-будівельна біоніка, природні аналоги будівель, біонічні принципи, конструктивні системи.

Keywords: large-span structures, engineering and construction bionics, natural analogs of buildings, bionic principles, structural systems.

Вступ. Використання чисельних методів та ЕОМ дозволило розширити знання i розробку принципів впровадження в практику проектування будівель і споруд природних аналогів, особливо в архітектурі, де розглядаються питання формоутворення об'єктів i ïx адаптація в навколишнє середовище. Однак, архітектурна біоніка потребує нових ефективних конструктивних систем 3 використанням природних аналогів, їх розрахунок, конструювання і впровадження в будівництво.

Аналіз останніх досліджень та публікацій. Пошук надійних природних аналогів і їх використання в просторових конструктивних системах - одна 3 найбільш актуальних задач сьогодення. В наш час великими темпами ведеться розробка нових варіантів просторових покриттів, які раніше не використовувалися, i немає досвіду в їx експлуатації. Апробація експериментальними дослідженнями на моделях ігнорується, а використовується лише чисельний експеримент.

В основному дослідження із цієї теми проводилися природознавцями та архітекторами [1 - 5]. Серед робіт, що вивчають конструктивні аналоги живої природи, слід відзначити [6 - 9].

На рис. 1,б наведено багатоцільовий міст в Сеулі довжиною 1080 м. Природним аналогом мосту послужила водомірка (рис. 1,a). 

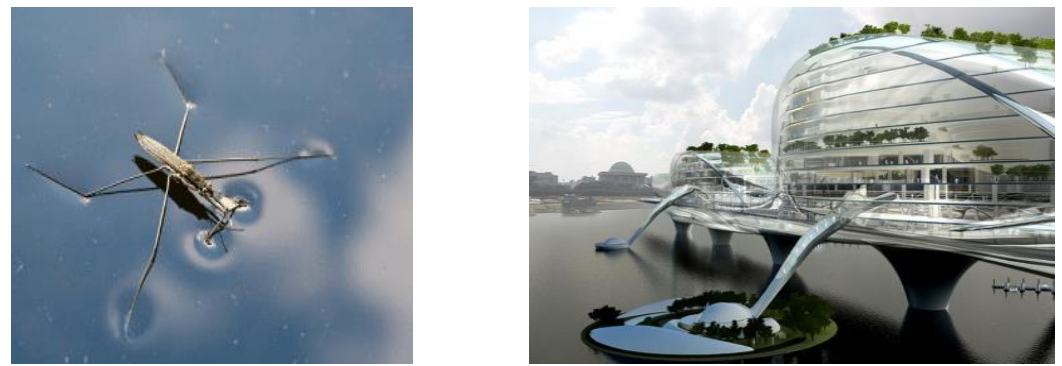

Рис. 1. $a$ - водомірка на воді; $\sigma$ - проект багатоцільового мосту в Сеулі

Радіолярій налічується близько 6000 видів (рис. 2,a), можна сказати: вони являють собою таке розмаїття форм, що їх з надлишком вистачить на створення тисяч нових архітектурних шедеврів.

«Три Грації» - проект голландської студії NOX, який складається 3 трьох веж, з'єднаних мостом (рис. 2,б). Форма мосту з вежами запозичена у радіолярій. Три унікальні вежі мають практично однакову висоту та форму і створюють чудовий архітектурний ансамбль.
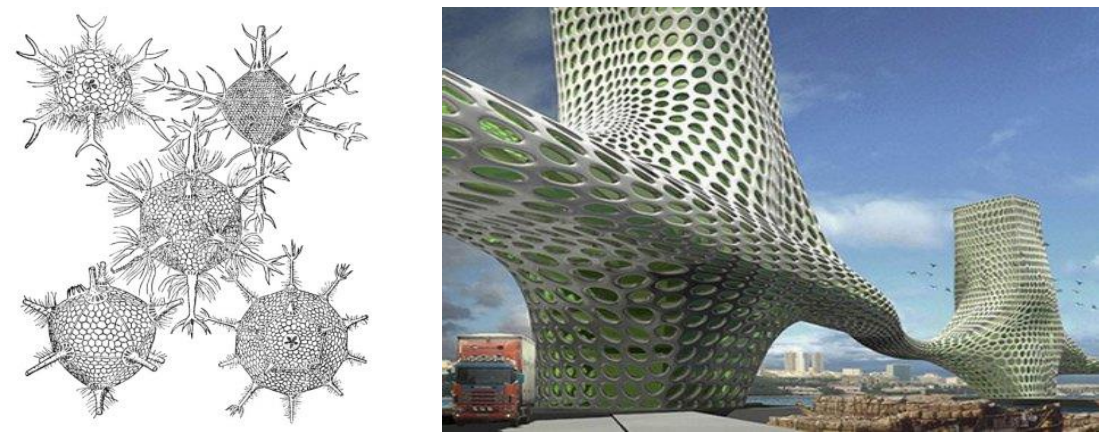

Рис. 2. $a$ - структури радіолярій; $\sigma$ - «Три Грації» - проект в Дубаї

Цілі і завдання. Виконати аналіз нових досліджень по застосуванню у великопролітних будівлях і спорудах біонічних принципів.

Основна частина. Проектні рішення великопролітних конструкцій постійно вдосконалюються. Ця необхідність викликана збільшенням габаритних розмірів будівель і споруд, а також отриманням нових експериментально-теоретичних результатів і впровадженням $\mathrm{y}$ будівництво нових надміцних матеріалів.

Отримати нові рішення великопролітних споруд можливо і на основі вивчення біоаналогів. 
На основі вивчення будови конструктивних аналогів живої природи встановлено принцип резільянсу [8] в конструктивних системах (resilience - пружність, еластичність, здатність швидко відновлювати внутрішні сили). За рахунок використання резільянсу в конструкції відновлюється іiі несуча здатність без збільшення маси. Виходячи 3 принципу резільянсу, були розроблені трансформовані конструкції покриттів.

На рис. 3 наведено музей творчості в Мілуокі (Вісконсін, США) архітектора Сантьяго Калатрави. Головний елемент будівлі музею - крила птаха, що рухаються. Кожне крило павільона складається 336 ребер довжиною від 8 до 32 м. Ця величезна кінетична конструкція білих крил в розкритому стані складає більше $60 \mathrm{~m}$. Час, необхідний для повного закриття/розкриття крил, складає 3 хвилини. Загальна маса конструкції 115 т. Якщо швидкість вітру перевищує 64 км/год, автоматична система закриває ці жалюзі.
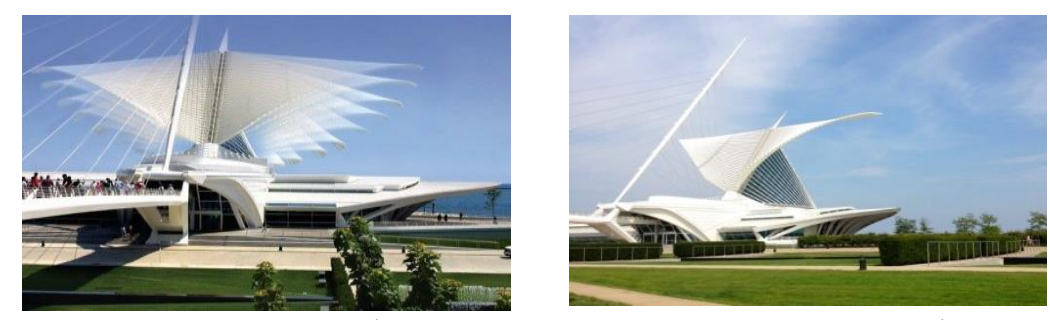

Рис. 3. $a$ - динаміка крил; $\sigma$ - крила в розкритому стані

Проте в найближчому майбутньому в будівництві необхідно зробити так, щоб конструкції мали живий рух, гнучкість і, крім того, інтелект. Зокрема, конструкція змінюється в форму, гармонізовану з навколишнім середовищем, і зміна форми реалізує більш універсальну функцію. В одному 3 механізмів, який робить можливим складний рух, є ферма зі змінною геометрією, яка названа VGT [10]. Як показано на рис. 4, $a$ VGT це просторова конструкція, яка складається 3 пружних елементів i шарнірів. Контролюючи довжину пружних елементів, можна створити різні форми просторової конструкції. Приклад зміни форми, що поєднує два розміри VGT послідовно, показані на рис. 4,б. 

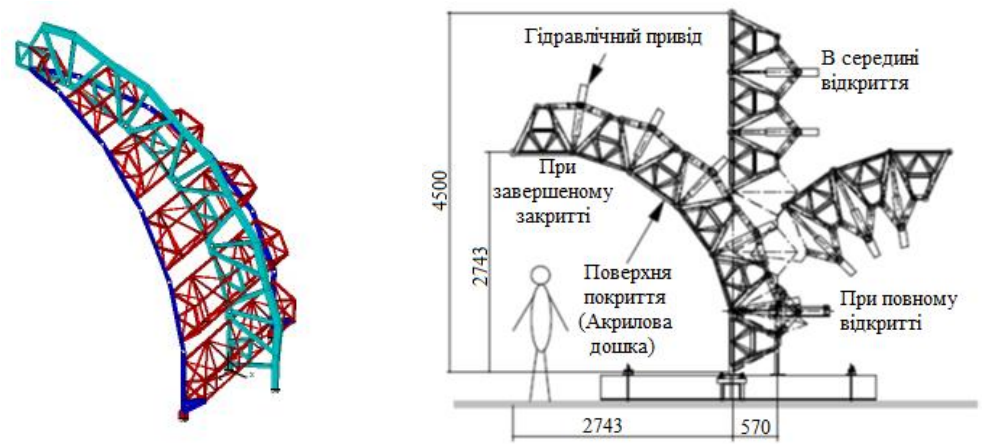

Рис. 4. $a$ - ферма VGT; $\sigma$ - зміни форми ферми

Згідно 3 принципом гетерогенного розміщення матеріалу в конструктивних системах, поєднання геометрії полігональних осередків зі слоїстістю і їх міцних стінок забезпечують компактність, високу міцність і жорсткість структурам при мінімальній витраті матеріалу. Використання шарів 3 різними властивостями дозволяе отримати конструкцію типу «сендвіч» 3 високою міцністю, жорсткістю і відносно малою вагою. Загальна стійкість конструкції з гетерогенним розміщенням матеріалу в багато разів перевищує стійкість окремих ï шарів, завдяки чому зовнішні шари 3 більш щільного матеріалу мають значно меншу товщину в порівнянні з внутрішнім шаром пористої структури. Останній виконує роль заповнювача, що утворює практично безперервну опору для зовнішніх шарів, тим самим оберігаючи їх від втрати стійкості при навантаженні.

Виставковий павільйон прольотом 216 м уздовж однієї сторони і висотою 48,8 м (рис. 5). Оболонка - двошарова, товщина кожного шару 65 мм у вершині і 120 мм на лініях перетину. Обидва залізобетонних шари розділені між собою на висоту від 1,8 до 3 м поздовжніми і поперечними ребрами.
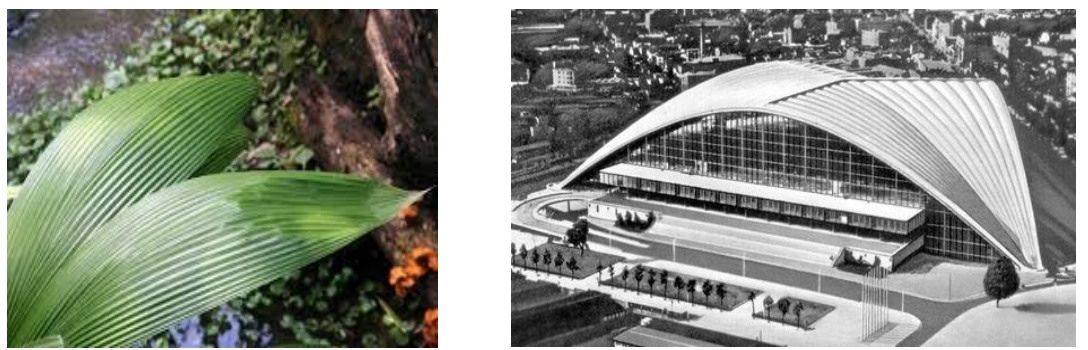

Рис. 5. $a$ - складчасте, жорстке листя тропічної рослини куркуліго відігнутого; $\sigma$ - виставковий павільйон у Парижі 
Принцип щільної упаковки дозволяє отримувати максимально корисний об'єм при мінімальній поверхні огородження. У природі він проявляється при оптимізації біологічних форм в тому випадку, коли осередки в структурі мають постійні геометричні характеристики. Так бджоли, будуючи стільники, утворюють щільну упаковку з кіл, які під дією капілярних сил, що перевищують тиск зсередини від бджолиних тіл, перетворюються в описані шестикутники. Розбиття площини на рівновеликі шестикутні елементи має мінімум довжини.

Метрополь Парасоль в Севільї - конструкція з дерева та залізобетону (рис. 6). Будівництво завершено в 2011 році. Об'єкт висотою 28 метрів займає площу 150 на 75 метрів і претендує на звання найбільшої конструкції з дерева в світі. Фігурні елементи зонтів в кількості 3400 штук скріплені 3000 несучими вузлами. Розміри елементів досягають до 16,5 м в довжину, а ширина змінюється від 68 до 311 см.

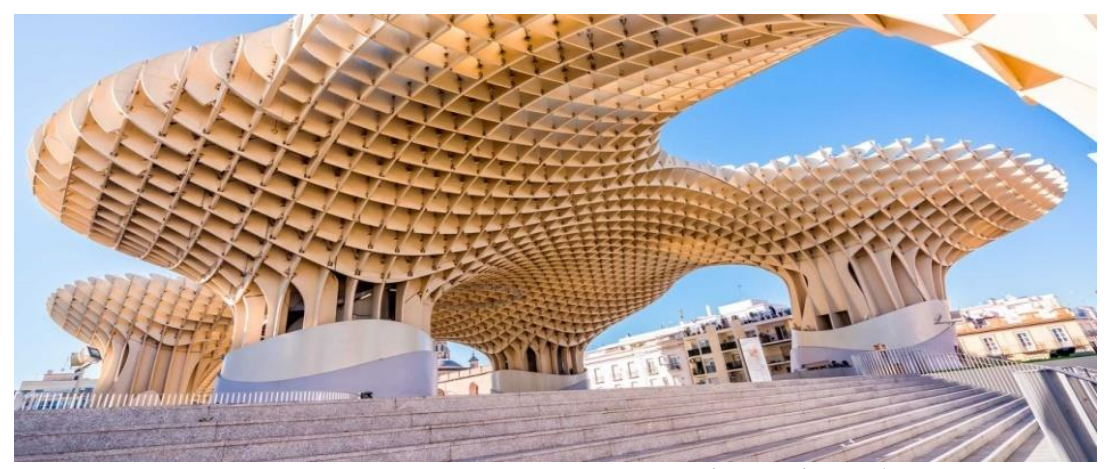

Рис. 6. Метрополь Парасоль - севільські гриби

Принцип спрямованої форми втрати стійкості дозволяє уникнути при проектуванні конструктивних систем біфуркації стійких форм рівноважних станів, а також виключити невизначеність їх подальшої поведінки під навантаженнями. Природа, створюючи конструктивні системи, свідомо намагається уникнути можливих переходів початкових деформацій в інші види, тобто виключає втрату стійкості першого роду. I це відбувається не шляхом посилення конструкцій живих організмів за рахунок збільшення маси, а кожній конструкції надається обрис відповідно до спрямованої форми втрати стійкості, що приймається за граничну стійкість 3 усіх можливих форм рівноваги. В результаті цього при статичній роботі виникає постійний вид деформацій.

На рис.7 [11] у вигляді горизонталей показано поле прогинів залізобетонної квадратної моделі - оболонки додатньої кривини, жорстко затисненої по контуру, побудоване на основі результатів експерименту. Місцеве збільшення прогинів при рівномірно розподіленому навантаженні 
отримано в місцях найбільших недосконалостей поверхні оболонки, виміряних до початку завантаження.
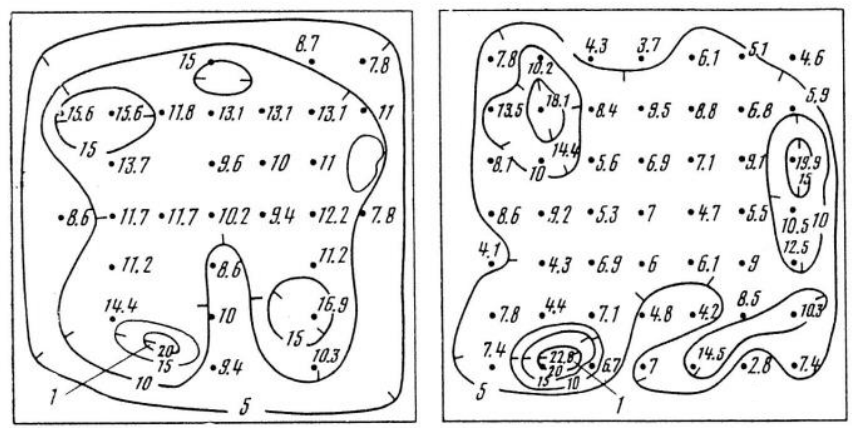

Рис.7. Поле прогинів: початкове (зліва); після навантаження (справа)

У природі простежуються способи боротьби 3 втратою стійкості: ребра підкріплення; гофри; гетерогенність - шарувата будова. Гетерогенна будова елементів біологічних конструкцій не тільки гальмує розвиток поверхневих тріщин, а й гасить коливання, викликані динамічними впливами, являючись свого роду демпфером.

Згідно з принципом траекторіальної будови конструктивних систем елементи в конструкціях живої природи розміщуються відповідно до геометрії поля переміщень по траєкторіях головних напружень. Характер силового поля визначається видом зовнішнього впливу і кінематичними граничними умовами. Траекторіальні структури забезпечують гранично обмеженим обсягом матеріалу вимоги необхідної міцності щодо заданих сил. Орієнтація елементів уздовж силових ліній підвищує міцність і жорсткісні властивості при мінімальному обсязі матеріалу, що йде на їх створення.

Взявши за основу жилкування листа Вікторії регії, що розміщено по траєкторіях головних напружень, італійський архітектор П. Нерві сконструював ребристе покриття фабрики Гатті в Римі (рис.8б).
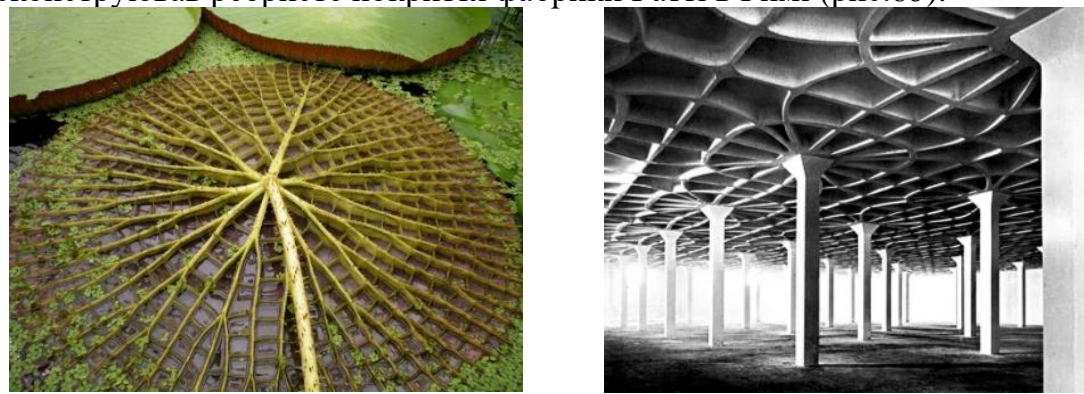

Рис. 8. $a$-лист Вікторії регіi; $\sigma$ - ребристе покриття фабрики Гатті 


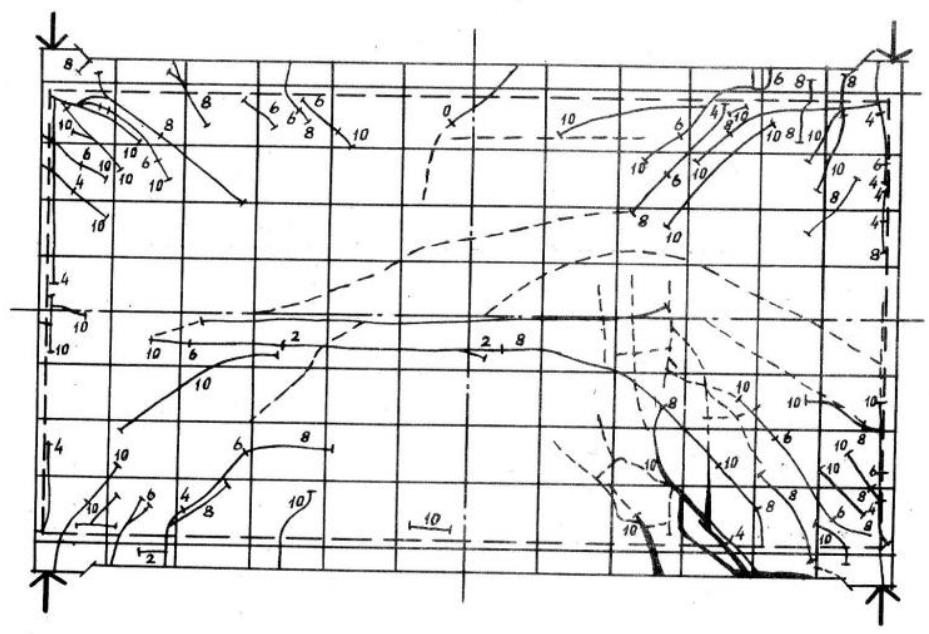

Рис. 9. Утворення тріщин по майданчиках головних напружень в моделі циліндричної відкритої оболонки середньої довжини під дією рівномірно розподіленого навантаження по плиті оболонки $\left(\mathrm{q}_{2}, \mathrm{H} / \mathrm{M}^{2}\right)$ і по поздовжніх бортових елементах (q0, Н/м), а саме по ступенях завантаження: №1 (500; 62), №2 (1000; 123), №3 (1500; 185), №4 (2000; 247), №5 (2500; 308), №6 (3000; 369), №7 (3500; 431), №8 (4000; 492), №9 (4500; 554), №10 (5000;

615), де перша цифра в дужках $\mathrm{q}_{2}$, друга - q0

Великий обсяг досліджень на моделях залізобетонних оболонок можна використати для визначення орієнтації головних майданчиків. Експериментами встановлено початок утворення тріщин в бетоні оболонок при навантаженнях: $0,3 \mathrm{q}_{\mathrm{p}}$ циліндричних відкритих; $0,4 \mathrm{q}_{\mathrm{p}}$ додатної кривизни; $0,5 \mathrm{q}_{\mathrm{p}}$ від'ємної кривизни ( $\mathrm{q}_{\mathrm{p}}$ - навантаження руйнування).

Слабкість бетону сприймати зусилля розтягу веде до утворення тріщин по головних майданчиках [11]. Картина тріщин вказує, як найкраще розміщувати матеріал в конструкції (рис. 9).

Висновки i перспективи досліджень. Наведено великопролітні просторові конструктивні системи, запроектовані 3 використанням сучасних біонічних принципів.

Можна зробити висновок, що розглянута досить складна проблема, яка $є$ актуальною і потребує подальшого вивчення. 


\section{References}

1. Sadri M. Bionic architecture, forms and constructions / M. Sadri, M. Kavandi, A. Jozepiri, S. Teimouri, F. Abbasi // Research Journal of Recent Sciences, 2014. - Vol. 3(3). - P. 93-98.

2. Saber R.H. Architectural Constructions Inspired by Nature / R. H. Saber, B. Daryayelaal // Journal of Basic and Applied Scientific Research, 2013. - Vol. 3(2). - P. 1037-1044.

3. Sugár V. Bionics in architecture / V. Sugár, P. Leczovics, A. Horkai // YBL Journal of built environment, 2017. - Vol. 5. - Issue 1. - P. 31-42.

4. Lebedev YU.S. Arkhitekturnaya bionika / YU.S. Lebedev, V.I. Rabinovich, Ye.D. Polozhay. - M.: Stroyizdat, 1990. -269 p.

5. Megahed N.A. Towards a bionic architecture in the context of sustainability / N.A. Megahed // Port-Said Engineering Research Journal, 2020. - Vol.16. - No. 2. - P. 181-189. https://www.researchgate.net/publication/344435727

6. Temnov V.G. Ekologiya i arkhitekturnaya tektonika stroitel'nykh ob"yektov gorodskoy sredy obitaniya / V.G. Temnov, G.Ye. Rusanov, S.A. Bolotin, A.L. Gel'fond // Voda i ekologiya: problemy i resheniya, 2017. - №4 (72) - P.95-102. doi:10.23968/2305-3488.2017.22.4.95-102

7. Byuttner O. Sooruzheniye - nesushchaya konstruktsiya - nesushchaya struktura: Analiz zhivoy prirody i gradoobrazuyushchey sredy / O. Byuttner, E. Khampe. - M.: Stroyizdat, 1983. $-340 \mathrm{p}$.

8. Temnov V.G. Avtomatizirovannyy sintez optimal'nykh uprugikh konstruktivnykh sistem na osnove bionicheskikh printsipov: avtoref. diss. ... dokt. tekhn. nauk: 05.13.12 / V.G. Temnov. - M.: MISI, 1991. -48 p.

9. Khazin V.Y. Mekhanichni pryntsypy arkhitektoniky roslyn $\mathrm{v}$ inzhenernobudivel'niy bionitsi / V.Y. Khazin, D.V. Serdyuk // Zbirnyk naukovykh prats' (haluzeve mashynobuduvannya, budivnytstvo). - Poltava: PoltNTU, 2011. - Vyp. 2 (30). - P. 227233.

10. Kolomiychuk H.P. Prostorova transformatsiya konstruktyvnykh elementiv suchasnykh obolonok pokryt' / H.P. Kolomiychuk, V.H. Kolomiychuk // Suchasni budivel'ni konstruktsiyi z metalu ta derevyny. - Odesa: ODABA, 2020. - Vypusk №24. - P. 71-80. doi:10.31650/2707-3068-2020-24-71-80

11. Kolomiychuk G.P. Tekhnicheskaya otsenka zhelezobetonnykh obolochek pokrytiya / G.P. Kolomiychuk // Visnyk ODABA, Odesa: ODABA, 2009. - Vyp. 34. Chastyna 2. - P. 428-435.

\section{Список використаних джерел}

1. Sadri M. Bionic architecture, forms and constructions / M. Sadri, M. Kavandi, A. Jozepiri, S. Teimouri, F. Abbasi // Research Journal of Recent Sciences, 2014. - Vol. 3(3). - P. 93-98. 
2. Saber R.H. Architectural Constructions Inspired by Nature / R. H. Saber, B. Daryayelaal // Journal of Basic and Applied Scientific Research, 2013. - Vol. 3(2). - P. 1037-1044.

3. Sugár V. Bionics in architecture / V. Sugár, P. Leczovics, A. Horkai // YBL Journal of built environment, 2017. - Vol. 5. - Issue 1. - P. 31-42.

4. Лебедев Ю.С. Архитектурная бионика / Ю.С. Лебедев, В.И. Рабинович, Е.Д. Положай. - М.: Стройиздат, 1990. - 269 с.

5. Megahed N.A. Towards a bionic architecture in the context of sustainability / N.A. Megahed // Port-Said Engineering Research Journal, 2020. - Vol.16. - No. 2. - P. 181-189. https://www.researchgate.net/publication/344435727

6. Темнов В.Г. Экология и архитектурная тектоника строительных объектов городской среды обитания / В.Г. Темнов, Г.Е. Русанов, С.А. Болотин, А.Л. Гельфонд // Вода и экология: проблемы и решения, 2017. - №4 (72) - С.95-102. doi:10.23968/2305-3488.2017.22.4.95-102

7. Бюттнер О. Сооружение - несущая конструкция - несущая структура: Анализ живой природы и градообразующей среды / О. Бюттнер, Э. Хампе. - М.: Стройиздат, 1983. - 340 с.

8. Темнов В.Г. Автоматизированный синтез оптимальных упругих конструктивных систем на основе бионических принципов: автореф. дисс. ... докт. техн. наук: 05.13.12 / В.Г. Темнов. - М.: МИСИ, 1991. - 48 с.

9. Хазін В.Й. Механічні принципи архітектоніки рослин в інженернобудівельній біоніці / В.Й. Хазін, Д.В. Сердюк // Збірник наукових праць (галузеве машинобудування, будівництво). - Полтава: ПолтНТУ, 2011. - Вип. 2 (30). - С. 227-233.

10. Коломійчук Г.П. Просторова трансформація конструктивних елементів сучасних оболонок покрить / Г.П. Коломійчук, В.Г. Коломійчук // Сучасні будівельні конструкції з металу та деревини. - Одеса: ОДАБА, 2020. - Випуск №24. - С. 71-80. doi:10.31650/2707-3068-2020-24-71-80

11. Коломийчук Г.П. Техническая оценка железобетонных оболочек покрытия / Г.П. Коломийчук // Вісник ОДАБА, Одеса: ОДАБА, 2009. - Вип. 34. Частина 2. - С. 428-435. 